\title{
Comparative nutraceutical properties of seeds of eight citrus varieties grown in Rawalpindi region
}

Shams Ur Rehman ${ }^{1,2 *}$, Kashif Sarfraz Abbasi ${ }^{2}$, Naveed Ul Haq ${ }^{1}$, Quasid Ahmad $^{1}$, Najeeb Ullah Taran ${ }^{3}$, Shoaib Ullah ${ }^{4}$, Syed Muhammad Asim² and Muhammad Sami Ullah Awan ${ }^{2}$

1. Department of Food Science and Technology, The University of Haripur-Pakistan

2. Institute of Food and Nutritional Sciences, PMAS-Arid Agriculture University Rawalpindi-Pakistan

3. Department of Food Science and Technology, University of Agriculture Peshawar-Pakistan

4. Department of Agriculture, Abdul Wali Khan University Mardan-Pakistan

*Corresponding author's email: sr_awan1@yahoo.com

Citation

Shams Ur Rehman, Kashif Sarfraz Abbasi, Naveed Ul Haq, Quasid Ahmad, Najeeb Ullah Taran, Shoaib Ullah, Syed Muhammad Asim and Muhammad Sami Ullah Awan. Comparative nutraceutical properties of seeds of eight citrus varieties grown in Rawalpindi region. Pure and Applied Biology. Vol. 9, Issue 1, pp1-9. http://dx.doi.org/10.19045/bspab.2020.90001

Received: 16/02/2019 Revised: 29/05/2019

Accepted: 09/08/2019

Online First: 20/09/2019

\section{Abstract}

Fruits and vegetables (F and V) are valuable for their micronutrients, but many Fruits and Vegetables in diverse growth areas have not been scientifically validated for these components. The nutraceutical characteristics of the seeds of eight citrus fruits grown in Pakistan (Rawalpindi region) were, therefore, investigated. Expectedly, the seeds of citrus varieties differed in moisture (44.5\% to 54.8\%), ash (0.97\% to $3.13 \%)$, crude protein $(5.61 \%$ to $4.06 \%)$, crude fat $(20.3 \%$ to $15.3 \%)$, crude fiber $(16.4 \%$ to $9.52 \%)$ and carbohydrates $(17.5 \%$ to $10.2 \%)$ contents. Potassium, sodium and magnesium were the major minerals, while iron, zinc and manganese were present in minor fractions in the seeds. Phytochemical analysis (total phenolic content, 129 to $99.1 \mu \mathrm{g} / \mathrm{g}$ GAE and total flavonoids content, 35.11 to $13.21 \mu \mathrm{g} / \mathrm{g}$ QE) revealed antioxidant potential that was confirmed by a high 1,1-diphenyl 1-2-picrylhydrazyl (DPPH) radical scavenging activity, showing a highly positive correlation $\left(\mathrm{r}^{2}>0.832,0.667 \mathrm{p}>0.05\right)$ with the measured antioxidant components (Total Phenolics and Total Flavonoids). The analysis shows a significant relationship between the citrus varieties and their quality parameters to guide their industrial potential as sources of nutraceuticals.

Keywords: Antioxidant constituent; Citrus varieties; Minerals constituent and Proximate constituent

\section{Introduction}

The genus Citrus, belonging to the Rutaceae family. The plants of most species of Citrus are large evergreen shrubs or small trees, 5$15 \mathrm{~m}$ tall. Citrus are recognized as one of the world's major fruit crops [1]. They are harvested in many countries with tropical or subtropical climate. World's production of citrus is 115.52 million tons, and in Pakistan it is resided at the area of 199 thousand hectares with total production of 2007 thousand tones in Pakistan. Citrus exported by Pakistan is 6.18 thousand tones, and its total import is 529 tones [2].

There were almost 170 phytochemicals found in citrus fruit amongst which 60 are 
flavonoids which shows antioxidant, antitumor, anti-inflammatory and blood clotting inhibiting characteristics [3]. It was consumed all over the world with many beneficial components like vitamin $\mathrm{C}$ act as an antioxidant that also enhances the human body immune system and for scavenging free radicals [4], vitamin A for skin and vision, vitamin B-complex like thiamin, folates and pyridoxine these are necessary in a sense that human body needs them from external sources to replenish [5]. Carotenoids present in citrus are lutein, beta-cryptoxanthin, violaxanthin, antheraxanthin, luteoxnthin, zeaxanthin, beta-carotene and alpha carotene [6].

Minerals are required in a very small amount for the maintenance of health, there are fourteen minerals essential for human body; these have some specified roles for regulation of human body functions [7]. The presence of total mineral content in fruits can be evaluated by the determination of ash content [8]. Genetic variation can cause the differences in total mineral content in citrus varieties [9]. Citrus fruit have reported as high potassium content and low sodium content, magnesium content in citrus fruit is relatively high [10]. Fruits are generally not considered to be the source of calcium but citrus fruit contain appreciable amount of calcium content. Zinc, iron and manganese were present in trace amount in citrus fruit [7].

Thus, this study aimed to assess the proximate constitutes, minerals constitutes and antioxidant compounds/activity of eight citrus varieties seeds. Objectives are set to attain the aim include the assessment of proximate constitute (moisture, ash, crude (fat, fiber and protein and carbohydrates), minerals constitute (major minerals $\mathrm{K}$ (potassium), $\mathrm{Na}$ (sodium) and $\mathrm{Mg}$ (magnesium), Minor minerals Fe (iron), Zn (zinc) and Mn (manganese) and antioxidant constituents (antioxidant compounds (total phenolicas and total flavonoids) and antioxidant activity (1, 1-diphenyl 1-2picrylhydrazyl radical scavenging activity) The result of this study may provide basis for beneficial use of citrus fruit seeds.

\section{Materials and methods Materials}

Eight citrus varieties, Citrus sinensis cv (Hamlin, Red blood, Succuri), Citrus limetta (Mosambi), Citrus reticulate (Tangerine), Citrus paradise macfed (Grape fruit), Citrus aurantium and Citrus jambhiri lush, were collected from the Rawalpindi Region of Pakistan. The fruits were washed, sorted, graded, stored at room temperature and seeds were separated prior to analysis. This study was conducted in the Department of Food Technology PMAS Arid Agriculture University Rawalpindi.

\section{Chemical analysis}

Moisture content (Model: 605, Precision Oven, Thermo Fisher Scientific; $105^{\circ} \mathrm{C}$ till constant weight), ash content (muffle furnace, lef-2055-0, Daihan Labtech, Korea, $550^{\circ} \mathrm{C}$ ), crude fiber (gravimetric enzymatic digestion procedure) were measured [11], crude protein (Kjel Tech apparatus) were measured [11], crude fat (soxhlet apparatus, solvent is diethyle ether) were measured [11] and carbohydrate content were measure by substracting all the above proximate contents from 100. The mineral content was determined [11] by digesting $5 \mathrm{~g}$ of the seed with $10 \mathrm{~mL}$ of a nitric acid:perchloric acid (7:3) mixture at $180-200^{\circ} \mathrm{C}$ till completion. The digest was made up to $100 \mathrm{~mL}$ with distilled water, and $\mathrm{Mg}, \mathrm{Fe}, \mathrm{Zn}$, and $\mathrm{Mn}$ contents of the seed were determined in an Atomic Absorption Spectrophotometer (GBC-932, Scientific Equipment Limited, Australia), whereas $\mathrm{Na}$ and $\mathrm{K}$ were measured by Flame Photometer (Model PFP 7, Jenway, England).

\section{Phytochemical analysis \\ Sample preparation}


During the extraction of antioxidants from the citrus seed samples, methanol was used to assess their extraction efficiency. The samples were subjected to orbital shaker for $7 \mathrm{hr}$ followed by centrifugation (model: 800 electronic centrifuge, RENONLAB, 1342 g for $10 \mathrm{~min}$. The supernatant was decanted, and the residue was re-dissolved in $10 \mathrm{~mL}$ of the methanol and centrifuged for $5 \mathrm{~min}$., before combining both supernatants (extracts) for the following analyses [12].

\section{Total phenolic content (TPC)}

One $\mathrm{mL}$ of the extract was oxidized with 2.5 $\mathrm{mL}$ of Folin-Ciocalteau's reagent (10\%), followed by neutralization with $2 \mathrm{~mL}$ sodium carbonate $(7.5 \%)$. The mixture was kept in the dark for $45 \mathrm{~min}$., and the absorbance was measured at $765 \mathrm{~nm}$ wavelength using a spectrophotometer (UV-9200, Biotech Engineering Management Co., UK). Gallic acid was used as the standard [13].

Total flavonoids content (TFC)

One $\mathrm{mL}$ of the extract was mixed with $0.3 \mathrm{ml}$ of sodium nitrite $(5 \%)$. After an interval of 5 min., $0.6 \mathrm{ml}$ of aluminum chloride $(10 \%)$ was added and mixed. This was followed by adding $2 \mathrm{~mL}$ of $1 \mathrm{M}$ sodium hydroxide after an interval of $5 \mathrm{~min}$., and the absorbance was measured at $510 \mathrm{~nm}$ wave length with the spectrophotometer. The total flavonoid was calculated using quercetin as a standard [14]. 1, 1-diphenyl 1-2-picrylhydrazyl (DPPH) Radical scavenging assay

An equal volume of the extract was added to methanolic solution of DPPH $(0.7 \mathrm{mM})$ and held for $30 \mathrm{~min}$. at room temperature before the absorbance was measured at $517 \mathrm{~nm}$ using the spectrophotometer. The percent of radical scavenging activity was calculated as the ratio of the absorbance of the sample,

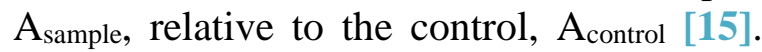
The control was the DPPH solution without the seed extract, and the radical scavenging activity was calculated as:

Radical scavenging activity $(\%)=100 \times$ ( $\left.\mathrm{A}_{\text {control }}-\mathrm{A}_{\text {sample }}\right) / \mathrm{A}_{\text {control }}$

\section{Statistical analysis}

Results were subjected to one-way analysis of variance (ANOVA). Statistical differences with P-values less than 0.05 were considered significant and means were compared by LSD test according to $[16,17]$. All analyses on the citrus seeds were triplicated.

\section{Results and discussion}

Knowledge about biochemical composition of citrus seed in different varieties is very important for various purposes including chemical profiling of citrus seeds, its antioxidant potential, mineral profiling and conversions of citrus seeds to different products enhancing the nutritional value and their functional characterization.

\section{Proximate constituents}

In (Table 1) shows the results for the moisture, ash, crude fiber, crude protein, crude fat, carbohydrates and there varietal differences. Proximate analysis disseminated that mean values of moisture content of seed in all the tested varieties were in a close range $44.5 \%$ to $54.8 \%$. Highest amount of moisture content was found in CLM 54.8\% followed by CRT $54.4 \%$. CAT was amongst the varieties with lowest moisture content $44.5 \%$. All the tested varieties contained small fractions of ash ranging from $0.97 \%$ to $3.13 \%$. CSH contain significantly high ash content with respect to other varieties while minimum ash content was observed in CLM. Maximum level of crude fiber $16.4 \%$ was seen in CJL followed by CSH with a close value of $14.3 \%$ while the lowest $9.52 \%$ was present in CLM. CJL and CSH were preferred over other citrus seed for its crude fiber content. Estimation of protein content indicated that CAT exhibited significantly highest protein content $5.61 \%$ as compared to other varieties that was followed by CSS $5.27 \%$. The lowest amount of protein was present in seed $4.06 \%$. A close range of crude fat content was observed in all the tested varieties $15.3 \%$ to $20.3 \%$. CPM contains high fat content $20.3 \%$ from all other tested 
varieties followed by CSR and CAT with a very close value of $20.2 \%$ and $20.1 \%$. While the lowest fat content amongst all other varieties was present in CRT (15.3\%). However in case of carbohydrate content maximum value was present in CAT (17.5\%) while the lowest was in CSH (10.2\%).

Correlations between different proximate contents of tested samples of citrus seed were delineated in the table 2 . A strong correlation was found between crude protein and carbohydrates $\left(\mathrm{R}^{2}=0.7739 \mathrm{p}<0.05\right)$, crude protein and crude fat $\left(\mathrm{R}^{2}=0.5700 \mathrm{p}<0.05\right)$ and between ash and crude fiber $\left(\mathrm{R}^{2}=0.5505\right.$ $\mathrm{p}<0.05)$. Correlation between other minerals was not so remarkable.

Citrus species are of prime economic importance in both fresh and processed fruit markets. All the tested varieties shows that seeds contain high concentration of crude fat which can be further processed in to high energy products. Crude fat content were found quiet comparable with those citrus grown in Nigeria that is 24.3\% [18]. However, the present oil yield was lower than those reported for Egyptian citrus (Orange, Mandarin, Lime and Grapefruit) seeds that is $40.2-45.5 \%$ [19]. The range of crude fat content (15.3-20.3\%) of citrus seeds in the present analysis was found to comparable with those of three conventional oilseed crops like cotton $15-24 \%$, soybean $17-21 \%$ and olive 20-25\% [20].

Due to the increasing in World population and the lack of animal protein, especially in the developing countries, the demand of both conventional and nonconventional plant protein increases [21]. All the tested citrus varieties contain high concentration of crude protein (4.06-5.61\%) in their seeds. The result of crude protein were in line with the finding of [1] that shows protein content of citrus (grape fruit and mosambi) seeds is $3.90 \%-5.56 \%$.

While another study were found lower protein content (3.1-3.2\%) in citrus seeds with respect to the finding of present study. Citrus seed shows high ash content as compared to citrus peel which indicates that these seeds contain high minerals in them and the results for ash content were in line with the finding of Egyptian citrus seeds 2.2-3.5\% [19].

High Crude fiber contents possessed by all citrus seeds (9.5-16.4\%) holds a significant nutraceutical importance in preventing and curing different disorders. Moisture content in citrus seeds was found lower than its pulp and peel. Carbohydrates in citrus seed contain celluloses and hemicelluloses which can be used as ruminants feed.

Table 1. Proximate constitute of seeds of eight citrus varieties

\begin{tabular}{|c|c|c|c|c|c|c|}
\hline Variety & $\begin{array}{c}\text { Moisture } \\
\text { \% }\end{array}$ & Ash \% & $\begin{array}{c}\text { Crude } \\
\text { fiber\% }\end{array}$ & $\begin{array}{c}\text { Crude } \\
\text { protein \% }\end{array}$ & Crude fat \% & $\begin{array}{c}\text { Carbohydrates } \\
\text { \% }\end{array}$ \\
\hline CSH & $47.6 \pm 0.4^{\mathrm{d}}$ & $3.13 \pm 0.23^{\mathrm{a}}$ & $14.3 \pm 0.4^{\mathrm{b}}$ & $4.43 \pm 0.1^{\mathrm{e}}$ & $20.1 \pm 0.8^{\mathrm{a}}$ & $10.2 \pm 1.4^{\mathrm{d}}$ \\
\hline CSR & $49.2 \pm 0.5^{\mathrm{c}}$ & $1.29 \pm 0.05^{\mathrm{e}}$ & $12.1 \pm 0.4^{\mathrm{c}}$ & $5.02 \pm 0.1^{\mathrm{c}}$ & $20.2 \pm 0.3^{\mathrm{a}}$ & $12.0 \pm 0.5^{\mathrm{c}}$ \\
\hline CSS & $50.6 \pm 0.7^{\mathrm{bc}}$ & $1.01 \pm 0.04^{\mathrm{f}}$ & $9.76 \pm 0.3^{\mathrm{de}}$ & $5.27 \pm 0.1^{\mathrm{b}}$ & $17.6 \pm 1.1^{\mathrm{b}}$ & $15.7 \pm 0.4^{\mathrm{b}}$ \\
\hline CLM & $54.8 \pm 1.6^{\mathrm{a}}$ & $0.97 \pm 0.06^{\mathrm{f}}$ & $9.52 \pm 0.2^{\mathrm{e}}$ & $4.16 \pm 0.1^{\mathrm{f}}$ & $17.7 \pm 1.3^{\mathrm{b}}$ & $12.7_{0.6^{\mathrm{c}}}$ \\
\hline CRT & $54.4 \pm 0.5^{\mathrm{a}}$ & $2.44 \pm 0.07^{\mathrm{b}}$ & $14.6 \pm 0.4^{\mathrm{b}}$ & $4.06 \pm 0.1^{\mathrm{f}}$ & $15.3 \pm 0.5^{\mathrm{c}}$ & $12.6 \pm 0.7^{\mathrm{c}}$ \\
\hline CPM & $51.1 \pm 0.4^{\mathrm{b}}$ & $1.96 \pm 0.07^{\mathrm{c}}$ & $9.8 \pm 0.3^{\mathrm{de}}$ & $4.74 \pm 0.1^{\mathrm{d}}$ & $20.3 \pm 0.8^{\mathrm{a}}$ & $11.9 \pm 0.6^{\mathrm{c}}$ \\
\hline CAT & $44.5 \pm 0.7^{\mathrm{e}}$ & $1.62 \pm 0.05^{\mathrm{d}}$ & $10.5 \pm 0.2^{\mathrm{d}}$ & $5.61 \pm 0.1^{\mathrm{a}}$ & $20.1 \pm 0.7^{\mathrm{a}}$ & $17.5 \pm 0.4^{\mathrm{a}}$ \\
\hline CJL & $47.2 \pm 0.3^{\mathrm{d}}$ & $1.89 \pm 0.05^{\mathrm{c}}$ & $16.4 \pm 0.9^{\mathrm{a}}$ & $4.75 \pm 0.1^{\mathrm{d}}$ & $16.6 \pm 0.3^{\mathrm{bc}}$ & $12.9 \pm 0.6^{\mathrm{c}}$ \\
\hline
\end{tabular}

Dissimilar letters with in the column indicated significant difference ( $\mathrm{p}<0.05)$. Meanof 3 values \pm corresponds to the standard error. CSH (Citrus sinensis hamlin), CSR (Citrus sinensis red blood) CSS (Citrus sinensis succuri, CLM (Citrus limetta mosambi), CRT (Citrus raticulata tangerine), CPM (Citrus paradise macfed, CAT (Citrus aurantium L), CJL (Citrus jambhiri lush). 
Table 2. Correlation between proximate constitute of seeds of eight citrus varieties.

\begin{tabular}{|l|l|l|l|l|l|l|}
\hline & Moisture & Ash & $\begin{array}{l}\text { Crude } \\
\text { fiber }\end{array}$ & $\begin{array}{l}\text { Crude } \\
\text { protein }\end{array}$ & $\begin{array}{l}\text { Crude } \\
\text { fat }\end{array}$ & Carbohydrates \\
\hline Moisture & 1 & & & & & \\
\hline Ash & -0.004 & 1 & & & & \\
\hline Crude fiber & -0.133 & 0.550 & 1 & & & \\
\hline Crude protein & -0.808 & -0.317 & -0.324 & 1 & & \\
\hline Crude fat & -0.448 & -0.194 & -0.640 & 0.570 & 1 & \\
\hline Carbohydrates & -0.590 & -0.364 & -0.327 & 0.773 & 0.227 & 1 \\
\hline
\end{tabular}

\section{Antioxidant constituents}

In (Table 3) shows the results for the total phenolics, total flavonoids, DPPH radical scavenging activity and there varietal differences. The amount of total phenolic was determined by comparing with the calibration curve of Gallic acid and results were expressed as $\mu \mathrm{g}$ GAE/g. The TPC in citrus seeds amongst all the tested varieties were in close range. Highest TPC was found in CJL $129 \mu \mathrm{g} \mathrm{GAE} / \mathrm{g}$ while the lowest was present in CLM $99.18 \mu \mathrm{g}$ GAE/g.

A standard curve of quercetin was prepared for the calculation of the amount of total flavonoids in citrus seeds. TFC in citrus peel amongst all the varieties were present in the range of $13.21 \mu \mathrm{g} \mathrm{QE} / \mathrm{g}$ in CLM to $35.11 \mu \mathrm{g}$ $\mathrm{QE} / \mathrm{g}$ in CSR. The highest amount of TFC in citrus seed amongst all the varieties were noted in CJL $22.80 \mu \mathrm{g}$ QE/g followed by CSR with a very close range of $22.60 \mu \mathrm{g}$ $\mathrm{QE} / \mathrm{g}$, while the lowest amount of TFC were noted in CPM 17.68 $\mu \mathrm{g}$ QE/g.

The antioxidant potential of citrus seed extract was evaluated as percent inhibition of DPPH free radicals. DPPH radical scavenging activity of citrus seed was in the close range of $40.313 \%$ in CLM to $54.30 \%$ in CJL. The values of antioxidant activities are in agreement with the trend observed for total phenolic and flavonoid contents.

In (Table 4) shows that Strong correlation was found between DPPH and TPC of citrus seed $\left(\mathrm{R}^{2}=0.8320, \mathrm{p}<0.05\right)$. The correlation found between DPPH and TFC $\left(\mathrm{R}^{2}=0.6678\right.$, $\mathrm{p}<0.05)$ was not strong, this indicates that TFC plays a minor role in antioxidant activity of citrus seed [22].

Scavenging the stable DPPH radical is a widely used model method to evaluate the free radical scavenging ability of different samples [6]. A previous study describes that the radical scavenging activity of all the citrus extracts increases with the increase in the concentration of phenolic and flavonoids. Variation observed in the total phenolic and flavonoid contents can be related to the genetic differences that incorporate variable biosynthesis pathways in different varieties and thus produce variable level of total phenolic and flavonoids [23].

The results for the phytochemicals composition expressed by present research partly coincide with the findings of [24]. Similar to our findings a strong correlation between TPC and antioxidant activity of citrus has been previously explained [25]. Several other studies have confirmed that citrus contain a moderate amount of antioxidants and the presence of phenolics in fruits is particularly important because of their health beneficial effects [26, 13].The antioxidant capacity of phenolic compounds is associated with their ability to quench free radicals, chelate pro-oxidant metal ions and inhibit some enzymes involved in the process of oxidation. Total phenolic contents can be taken as a key indicator of antioxidant potential in citrus fruit [27]. 
Table 3. Antioxidant constitute of seeds of eight citrus varieties

\begin{tabular}{|c|c|c|c|}
\hline Variety & DPPH & TPC & TFC \\
\hline CSH & $46.4 \pm 0.9^{\mathrm{bc}}$ & $106 \pm 2.4^{\mathrm{d}}$ & $20.1 \pm 2.2^{\mathrm{bc}}$ \\
\hline CSR & $53.6 \pm 2.1^{\mathrm{a}}$ & $118 \pm 3.7^{\mathrm{b}}$ & $22.60 \pm 0.7^{\mathrm{a}}$ \\
\hline CSS & $44.3 \pm 2.5^{\mathrm{c}}$ & $101 \pm 3.1^{\mathrm{e}}$ & $20.3 \pm 0.9^{\mathrm{bc}}$ \\
\hline CLM & $40.3 \pm 2.5^{\mathrm{d}}$ & $99.1 \pm 2.3^{\mathrm{e}}$ & $19.37 \pm 0.6^{\mathrm{c}}$ \\
\hline CRT & $53.3 \pm 2.1^{\mathrm{a}}$ & $112 \pm 2.2^{\mathrm{c}}$ & $21.5 \pm 0.6^{\mathrm{ab}}$ \\
\hline CPM & $45.0 \pm 1.3^{\mathrm{c}}$ & $106 \pm 3.8^{\mathrm{d}}$ & $17.68 \pm 0.8^{\mathrm{d}}$ \\
\hline CAT & $48.9 \pm 2.0^{\mathrm{b}}$ & $107 \pm 2.8^{\mathrm{d}}$ & $20.8 \pm 1.2^{\mathrm{bc}}$ \\
\hline CJL & $54.3 \pm 2.1^{\mathrm{a}}$ & $129 \pm 4.3^{\mathrm{a}}$ & $22.80 \pm 0.6^{\mathrm{a}}$ \\
\hline
\end{tabular}

Dissimilar letters with in the column indicated significant difference ( $\mathrm{p}<0.05)$. Mean of 3 values \pm corresponds to the standard error. DPPH (antioxidant activity), TPC (total phenolic content, TFC (total flavonoid content). CSH (Citrus sinensis hamlin), CSR (Citrus sinensis red blood) CSS (Citrus sinensis succuri), CLM (Citrus limetta mosambi), CRT (citrus raticulata tangerine), CPM (citrus paradise macfed, CAT (Citrus aurantium L), CJL (Citrus jambhiri lush).

Table 4. Correlation between antioxidant constitute of seeds of eight citrus varieties.

\begin{tabular}{|c|c|c|c|}
\hline Correlation & DPPH & TPC & TFC \\
\hline DPPH & 1 & & \\
\hline TPC & 0.832 & 1 & 1 \\
\hline TFC & 0.697 & 0.667 & \\
\hline
\end{tabular}

\section{Mineral constituents}

In (Table 5) shows the results for the sodium, potassium, magnesium, iron, zinc, manganese and there varietal differences. The mean value for sodium content in all the tested samples were ranged from 110 $\mathrm{mg} / 100 \mathrm{~g}$ to $153 \mathrm{mg} / 100 \mathrm{~g}$. Maximum amount of sodium was found in CJL $153 \mathrm{mg} / 100 \mathrm{~g}$ followed by CSR with a very close value of $145 \mathrm{mg} / 100 \mathrm{~g}$. Minimum amount of sodium was estimated in CSH $110 \mathrm{mg} / 100 \mathrm{~g}$. The low level of sodium in orange seeds makes them suitable for use in sodium restricted diets [28]. Determination of potassium in all the samples of citrus seed indicated that it was the chief mineral element in all samples with the range starting from $447 \mathrm{mg} / 100 \mathrm{~g}$ in CSH to $598 \mathrm{mg} / 100 \mathrm{~g}$ in CSR and the values are significantly different between each other. High potassium intake reduces blood pressure that also reduces the risk of cardiovascular disease. High potassium intake also protects a human to be diabetic [29]. All the analyzed samples CRT seed turn out to is the richest source of magnesium 22.9 $\mathrm{mg} / 100 \mathrm{~g}$ followed by CSH $21.2 \mathrm{mg} / 100 \mathrm{~g}$. lowest amount of magnesium was estimated in CAT $10.1 \mathrm{mg} / 100 \mathrm{~g}$ ). In a similar study, found that magnesium is essential for enzymes action, balance hormones, a healthy nervous and for cardiovascular system [30]. Out of all the eight tested varieties of citrus, CSH was preferred for their iron content 8.71 $\mathrm{mg} / 100 \mathrm{~g}$ followed by CJL $8.20 \mathrm{mg} / 100 \mathrm{~g}$. Lowest amount of iron was found in CSS $3.65 \mathrm{mg} / 100 \mathrm{~g}$. The present research revealed that the mean values for zinc in all the tested samples were in close range i.e. 2.39 $\mathrm{mg} / 100 \mathrm{~g}$ in CSR and the lowest in CSS 1.19 $\mathrm{mg} / 100 \mathrm{~g}$. All the tested samples contain small fraction of manganese ranging from $0.7933 \mathrm{mg} / 100 \mathrm{~g}$ in CPM to $1.56 \mathrm{mg} / 100 \mathrm{~g}$ in CLM. The ample amount of these minerals present in citrus peel is also required by plants for their normal growth [31].

All the tested samples of peel of the selected citrus varieties were found a rich source of potassium, magnesium and sodium and moderate levels of iron, zinc and manganese [10]. The significant difference in the means 
of mineral contents in the seed of all the tested citrus varieties depicted that minerals variation were depend on the genetic variations from variety to variety and it also depend upon the soil chemistry from which the plants uptake minerals. The variation of mineral content is also probably due to variation in the origin of varieties, quantity of fertilizer applied and mode of ripening [32].

Table 5. Mineral constitute of seeds of eight citrus varieties

\begin{tabular}{|c|c|c|c|c|c|c|}
\hline Variety & $\begin{array}{c}\mathbf{N a} \\
\mathbf{m g} / \mathbf{1 0 0 g}\end{array}$ & $\begin{array}{c}\mathbf{K} \\
\mathbf{m g} / \mathbf{1 0 0 g}\end{array}$ & $\begin{array}{c}\mathbf{M g} \\
\mathbf{m g} / \mathbf{1 0 0 g}\end{array}$ & $\begin{array}{c}\mathbf{F e} \\
\mathbf{m g} / \mathbf{1 0 0 g}\end{array}$ & $\begin{array}{c}\mathbf{Z n} \\
\mathbf{m g} / \mathbf{1 0 0 g}\end{array}$ & $\begin{array}{c}\mathbf{M n} \\
\mathbf{m g} / \mathbf{1 0 0 g}\end{array}$ \\
\hline CSH & $110 \pm 4.0^{\mathrm{e}}$ & $447 \pm 4.7^{\mathrm{f}}$ & $21.2 \pm 1.6^{\mathrm{b}}$ & $8.71 \pm 0.2^{\mathrm{a}}$ & $2.29 \pm 0.21^{\mathrm{ab}}$ & $1.36 \pm 0.06^{\mathrm{b}}$ \\
\hline CSR & $145 \pm 2.8^{\mathrm{b}}$ & $598 . \pm 5.5^{\mathrm{a}}$ & $16.8 \pm 3.1^{\mathrm{de}}$ & $7.58 \pm 0.3^{\mathrm{c}}$ & $2.39 \pm 0.28^{\mathrm{a}}$ & $1.21 \pm 0.04^{\mathrm{c}}$ \\
\hline CSS & $136 \pm 4.3^{\mathrm{c}}$ & $490 \pm 5.6^{\mathrm{d}}$ & $18.2 \pm 0.5^{\mathrm{c}}$ & $3.65 \pm 0.2^{\mathrm{g}}$ & $1.19 \pm 0.15^{\mathrm{f}}$ & $1.02 \pm 0.07^{\mathrm{e}}$ \\
\hline CLM & $132 \pm 4.2^{\mathrm{c}}$ & $534 \pm 3.1^{\mathrm{b}}$ & $13.1 \pm 0.5^{\mathrm{f}}$ & $4.95 \pm 0.2^{\mathrm{e}}$ & $1.81 \pm 0.06^{\mathrm{de}}$ & $1.56 \pm 0.01^{\mathrm{a}}$ \\
\hline CRT & $117 \pm 4.8^{\mathrm{d}}$ & $392 \pm 4.7^{\mathrm{g}}$ & $22.9 \pm 0.4^{\mathrm{a}}$ & $6.60 \pm 0.2^{\mathrm{d}}$ & $2.14 \pm 0.10^{\mathrm{bc}}$ & $1.40 \pm 0.03^{\mathrm{b}}$ \\
\hline CPM & $121 \pm 2.5^{\mathrm{d}}$ & $462 \pm 4.0^{\mathrm{e}}$ & $17.5 \pm 0.4^{\mathrm{cd}}$ & $4.35 \pm 0.2^{\mathrm{f}}$ & $1.97 \pm 0.09^{\mathrm{cd}}$ & $0.79 \pm 0.04^{\mathrm{f}}$ \\
\hline CAT & $141 \pm 3.2^{\mathrm{b}}$ & $508 \pm 5.5^{\mathrm{c}}$ & $10.1 \pm 0.3^{\mathrm{g}}$ & $7.04 \pm 0.2^{\mathrm{d}}$ & $1.33 \pm 0.04^{\mathrm{f}}$ & $1.10 \pm 0.04^{\mathrm{d}}$ \\
\hline CJL & $153 \pm 2.0^{\mathrm{a}}$ & $451 \pm 2.6^{\mathrm{f}}$ & $16.1 \pm 0.4^{\mathrm{e}}$ & $8.20 \pm 0.1^{\mathrm{b}}$ & $1.61 \pm 0.11^{\mathrm{e}}$ & $1.52 \pm 0.06^{\mathrm{a}}$ \\
\hline
\end{tabular}

Dissimilar letters with in the column indicated significant difference ( $p<0.05)$. Mean of 3 values \pm corresponds to the standard error. $\mathrm{Na}$ (sodium), $\mathrm{K}$ (potassium), Mg (magnesium), $\mathrm{Fe}$ (iron), Zn (zinc), Mn (manganese).CSH (Citrus sinensis hamlin), CSR (Citrus sinensis red blood) CSS (Citrus sinensis succuri, CLM (Citrus limetta mosambi), CRT (Citrus raticulata tangerine),CPM (Citrus paradise macfed), CAT (Citrus aurantium L), CJL (Citrus jambhiri lush).

\section{Conclusion}

From the eight citrus varieties of the Rawalpindi district of Pakistan, differences were measured in the proximate, antioxidant and mineral constitute. The Citrus jambhiri Lush was effectively the best in the tested components due to presence of higher amount of antioxidant components/activity and iron. The Citrus aurantium $L$ had the highest contents of crude protein, carbohydrates and potassium. The study revealed how citrus varieties can be developed for antioxidant potential to initiate the production of functional products, and the correlations between the quality attributes reported can help in the selection of varieties for targeted products.

\section{Authors' contributions}

Conceived and designed the experiments: $S$ Rehman \& KS Abbasi, Performed the experiments: S Rehman, MSU Awan \& SM Asim, Analyzed the data: Na Haq \& N Taran, Contributed materials/ analysis/ tools: Q Ahmad \& S Ullah, Wrote the paper: S Rehman \& S Ullah.

\section{Acknowledgements}

The authors acknowledge Department of Food Technology, PMAS-Arid Agriculture University, Rawalpindi, Pakistan, for providing facilities for the completion of this research work.

\section{References}

1. Anwar F, Naseer R, Bhanger MI, Ashraf S, Talpur FN, \& Aladedunye FA (2008). Physico-chemical characteristics of citrus seeds and seed oils from Pakistan. J Am Oil Chem Soc 85(4): 321330.

2. FAO (2014).Citrus Fruit Statistics. Food and Agriculture Organization; United Nation Rome (Italy).

3. Cha JY, Cho YS, Kim I, Anno T, Rahman SM, \& Yanagita T (2001). Effect of hesperetin, a citrus flavonoid, on the liver triacylglycerol content an phosphatidate phosphohydrolase activity in orotic acid-fed rats. Plant Food Hum Nutr 56(4): 349-358.

4. Etebu E, \& Nwauzoma AB (2014). A review on sweet orange (Citrus sinensis $L$ Osbeck): health, diseases and 
management. Am J Res Commun 2(2): 33-70.

5. Tsuda H, Ohshima Y, Nomoto H, Fujita KI, Matsuda E, Iigo M, \& Moore MA (2004). Cancer prevention by natural compounds. Drug Metab Pharmacokinet 19(4): 245-263.

6. Lee SE, Hwang HJ, Ha JS, Jeong HS, \& Kim J (2003). Screening of medicinal plant extracts for antioxidant activity. Life sci 73(2): 167-179.

7. Paul DK, \& Shaha RK (2004). Nutrients, vitamins and minerals content in common citrus fruits in the northern region of Bangladesh. Pak J Biol Sci 7(2): 238.

8. Yan L, Gupta RP, \& Wall TF (2001). The implication of mineral coalescence behaviour on ash formation and ash deposition during pulverised coal combustion. Fuel 80(9): 1333-1340.

9. Roach DA, \& Wulff RD (1987). Maternal effects in plants. Annu Rev Ecol Evol Syst 18(1): 209-235.

10. De Moraes Barros HR, de Castro Ferreira TAP, \& Genovese MI (2012). Antioxidant capacity and mineral content of pulp and peel from commercial cultivars of citrus from Brazil. Food Chem 134(4): 1892-1898.

11. AOAC (2005). Official Method of Analysis. 18th Ed. Gaithersburg: MD. AOAC Press.

12. Rusak G, Komes D, Likić S, Horžić D, $\&$ Kovač M (2008). Phenolic content and antioxidative capacity of green and white tea extracts depending on extraction conditions and the solvent used. Food Chem 110(4): 852-858.

13. Anagnostopoulou MA, Kefalas P, Papageorgiou VP, Assimopoulou AN, \& Boskou D (2006). Radical scavenging activity of various extracts and fractions of sweet orange peel (Citrus sinensis). Food Chem 94(1): 19-25.
14. Toh JJ, Khoo HE, \& Azrina A (2013). Comparison of antioxidant properties of pomelo [Citrus Grandis (L) Osbeck] varieties. Int Food Res J 20(4).

15. Mishra K, Ojha H, \& Chaudhury NK (2012). Estimation of antiradical properties of antioxidants using DPPH assay: A critical review and results. Food Chem 130(4): 1036-1043.

16. Steel RGD, Torrie JH, Dickey DA (1997). Principles and Procedures of statistics: A Biometrical Approach. 3rd Ed. New York; USA. McGraw Hill Book co.

17. Abdel-Fari IB, Jahangir, van den Hondel CAMJJ, Kim HK, Choi YH, \& Verpoorte R (2009). Fungal infectioninduced metabolites in Brassica rapa. Plant Sci 176(5): 608-615.

18. Ajewole K, \& Adeyeye A (1993). Characterisation of Nigerian citrus seed oils. Food Chem 47(1): 77-78.

19. Habib MA, Hammam MA, Sakr AA, \& Ashoush YA (1986). Chemical evaluation of Egyptian citrus seeds as potential sources of vegetable oils. $J$ Amer Oil Chem Soc 63(9): 1192-1196.

20. Rossell JB \& Pritchard JLR (1991). Analysis of oil seeds, fats and fatty foods. Elsevier Science Publishers; Ltd.

21. Atta MB, \& El-shenawi GM (2013). Functional properties and in-vitro digestibility of bitter orange (Citrus aurantium) seed flour. MRJASSS 1(3): 042-047.

22. Xu G, Liu D, Chen J, Ye X, Ma Y, \& Shi J (2008). Juice components and antioxidant capacity of citrus varieties cultivated in China. Food Chem 106(2): 545-551.

23. Rababah TM, Ereifej KI, \& Howard L (2005). Effect of ascorbic acid and dehydration on concentrations of total phenolics, antioxidant capacity, 
anthocyanins, and color in fruits. J Agri Food Chem 53(11): 4444-4447.

24. Ghasemi K, Ghasemi Y, \& Ebrahimzadeh MA (2009). Antioxidant activity, phenol and flavonoid contents of 13 citrus species peels and tissues. Pak J Pharm Sci 22(3): 277-281.

25. Ghafar MF, Prasad KN, Weng KK, \& Ismail A (2010). Flavonoid, hesperidine, total phenolic contents and antioxidant activities from Citrus species. Afri $J$ Biotechno 9(3).

26. Fallico B, Ballistreri G, Arena E, Brighina S, \& Rapisarda P (2017). Bioactive compounds in blood oranges (Citrus sinensis (L.) Osbeck): Level and intake. Food Chem 215: 67-75.

27. Zou Z, Xi W, Hu Y, Nie C, \& Zhou Z (2016). Antioxidant activity of Citrus fruits. Food Chem 196: 885-896.

28. Kawasaki T, Delea CS, Bartter FC \& Smith H (1978). The effect of highsodium and low-sodium intakes on blood pressure and other related variables in human subjects with idiopathic hypertension. Am J Med 64(2): 193-198.

29. He FJ, \& MacGregor GA (2008). Beneficial effects of potassium on human health. Physiol Plan 133(4): 725735.

30. Reinhart RA (1988). Magnesium metabolism: a review with special reference to the relationship between intracellular content and serum levels. Arch Intern Med 148(11): 24152420.

31. Landeweert R, Hoffland E, Finlay RD, Kuyper TW, \& van Breemen N (2001). Linking plants to rocks: ectomycorrhizal fungi mobilize nutrients from minerals. Trends Ecol Evol 16(5): 248254.

32. Sinclair WA, \& Griffiths HM (2000). Variation in aggressiveness of ash yellows phytoplasmas. Plant Dise 84(3): 282-288. 